\title{
Photochemistry of dicarbonyl-substituted benzenes: influence of steric and electronic factors in the cyclization and Diels-Alder trapping reactions of photoenols
}

\author{
Jarugu Narasimha Moorthy* and Subhas Samanta \\ Department of Chemistry, Indian Institute of Technology, Kanpur 208016, India \\ E-mail:moorthy@iitk.ac.in
}

Dedicated to Prof. Waldemar Adam on the occasion of his 70th birthday

\begin{abstract}
We have examined the photochemistry of a broad set of diketones 1-6 containing $o$-methyl substituents. Whereas sterically-congested diketones $\mathbf{1}$ and $\mathbf{2}$ are found to undergo diphotocyclization to afford high yields of bis-benzocyclobutenols (BCBs), photolysis of 3, 4 and 6, which are devoid of steric congestion, is found to lead to an intractable material; in these cases, the initially formed photoenols appear to derive stabilization from the second electron withdrawing group (electronic effect) such that other competing reactions become promoted. Quite remarkably, it is these ketones that undergo very efficient tandem photoenolization-DielsAlder cycloaddition reactions in the presence of an excellent dienophile such as $N$ phenylmaleimide to yield novel Diels-Alder cycloadducts in near quantitative yields. Photolysis of sterically-encumbered ketones 1, 2 and 5 in the presence of $N$-phenylmaleimide is found to result in the suppression of the formation of benzocyclobutenols with virtually insignificant formation of the product; the short-lived photoenols appear to revert rapidly to the precursor ketones. Thus, we have unraveled a subtle role of steric and electronic factors in the diphotocyclization and 2-fold tandem photoenolization-Diels-Alder cycloaddition reactions of diketones.
\end{abstract}

Keywords: Photoenolization, photocyclization, benzocyclobutenols, Diels-Alder cycloaddition, ketones and dienols

\section{Introduction}

Benzocyclobutenols are considered as masked equivalents of $o$-xylylenols/dienols due to the fact that their thermolysis leads to the latter in a facile manner. ${ }^{1}$ In addition to their utility as diene intermediates in diverse Diels-Alder cycloaddition reactions, benzocyclobutenols can be 
structurally elaborated into heterocyclic aromatics by treatment with a base followed by reaction with appropriate electrophiles. ${ }^{2}$ Mechanistically, the formation of benzocyclobutenols has been a subject of several investigations. The mechanism based on incisive analysis of the photoreactivity of $o$-alkyl aryl ketones by Wagner et al. is shown in Scheme $1{ }^{3}$ The initial $\gamma$ hydrogen abstraction by the triplet-excited carbonyl produces a triplet $o$-xylylenol/biradical, which decays to the ground state $o$-xylylenols with both ' $E$ ' and ' $Z$ ' configurations of the $\mathrm{OH}$ group. The $(Z)$-photoenol is very short-lived and reverts to the starting ketone by a rapid [1,5]sigmatropic $\mathrm{H}$-shift. On the other hand, $(E)$-enol undergoes thermal conrotatory ring closure to the benzocyclobutenol. The latter has been shown to be responsible for acid/base-catalyzed reketonization, ${ }^{4}$ benzylic H/D exchange ${ }^{5 \mathrm{a}}$ and bimolecular Diels-Alder cycloaddition reactions. $^{1 \mathrm{a}, 5}$ Our recent investigations on the solid-state photoreactivity of $o$-alkyl aromatic aldehydes lend credence to this mechanism. ${ }^{6 a}$ Accordingly, the $(E)$-enols that are more thermodynamically stable resist cyclization and lend themselves to the phenomenon of photochromism, ${ }^{6 \mathrm{~b}}$ while those that are sterically-encumbered and less stable undergo rapid cyclization to benzocyclobutenols. ${ }^{7}$

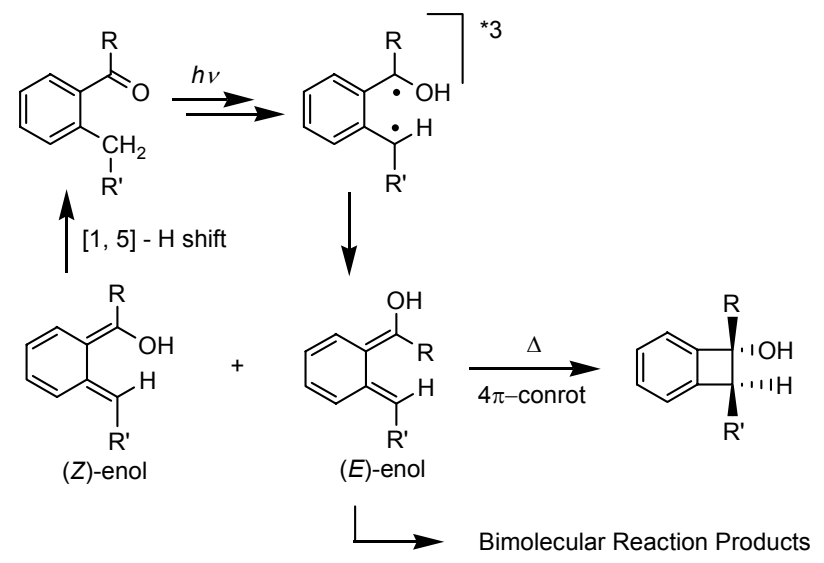

\section{Scheme 1}

Insofar as the tandem photoenolization and Diels-Alder cycloaddition reaction in the presence of a dienophile is concerned, it is indeed surprising that the factors that affect the latter process have been virtually unexplored, despite a high potential of this domino reaction ${ }^{8}$ in the realm of organic synthesis. Clearly, any factor that contributes to the persistence of $(E)$-enols should facilitate the trapping by a dienophile at the expense of unimolecular thermal conrotatory cyclization.

In continuation of our studies on the solid-state photochemistry of $o$-alkyl aromatic aldehydes, ${ }^{9}$ we wondered if i) bis-benzocyclobutenols can be accessed via diphotocyclization of dialkyl dicarbonyl compounds and ii) 2-fold tandem photoenolization and Diels-Alder cycloaddition can be accomplished with dialkyl dicarbonyl compounds. Incidentally, bisbenzocyclobutenols are difficult to be prepared from conventional synthesis and their utility in 
organic synthesis remains yet unexplored. ${ }^{1 b}$ As for the 2-fold Diels-Alder trapping of bisphotoenols generated from dicarbonyl compounds is concerned, Meador and co-workers have shown that novel structures can be accessed via this protocol. ${ }^{10}$ In the present investigation, we have explored the photochemistry of di/tri/tetramethyl-substituted dicarbonyl compounds 1-6 with the following objectives; the ketones 1, 2 and 5 containing two methyls ortho to the carbonyl group are considered to be sterically congested, while those that contain only one methyl, i.e., 3, $\mathbf{4}$ and $\mathbf{6}$, are not.

- how does the steric congestion influence diphotocyclization of dicarbonyl compounds to bisbenzocyclobutenols?

- how does the electron-withdrawing propensity of one carbonyl group influence the initially formed mono-photoenol?

- how is the 2-fold trapping with a dienophile influenced by the steric and electronic factors inherent to the diketones?
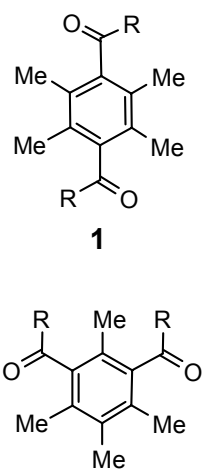

2

a: $\mathrm{R}=\mathrm{Ph} ; \mathbf{b}: \mathrm{R}=\mathrm{Me}$ c: $R=E t ; d: R=B n$
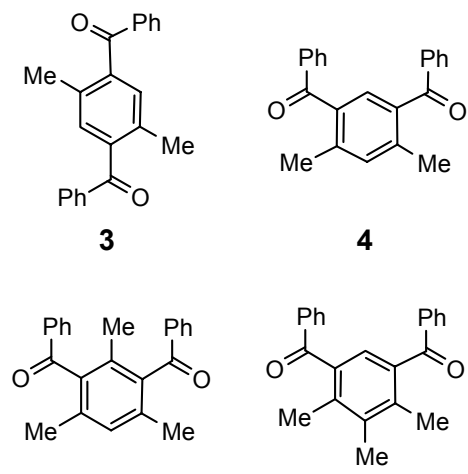

5

6

\section{Chart 1}

\section{Results and Discussion}

\section{Synthesis of ketones 1-6}

The synthesis of ketones 1-6 was accomplished by a 2-fold Grignard reaction using RMgX with appropriately methylated precursor dialdehydes followed by oxidation with PCC or Jones (for 1d and 2d) reagent. ${ }^{11}$ For example, the synthetic route for $\mathbf{1 a}$ is shown in eq 1.

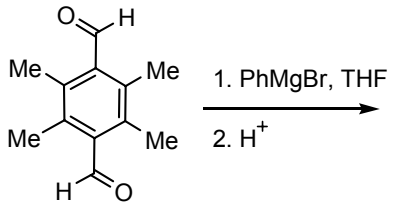<smiles>Cc1c(C)c(C(O)c2ccccc2)c(C)c(C)c1C(O)c1ccccc1</smiles><smiles>CC(C)(C)[Pb]</smiles><smiles>Cc1c(C)c(C(=O)c2ccccc2)c(C)c(C(=O)c2ccccc2)c1C</smiles>

$1 \mathrm{a}$ (eq 1) 
The precursor dialdehydes of ketones 1, 3, 4 and 5 were synthesized by literature-reported procedures. ${ }^{12,6 a, 6 \mathrm{~b}}$ The precursor dialdehydes for ketones $\mathbf{2}$ and $\mathbf{6}$ were synthesized by DIBAL-H reduction of the corresponding isophthalonitrile derivatives (eq 2). The latter were synthesized by following the reported synthetic protocols. ${ }^{6 a, 13}$

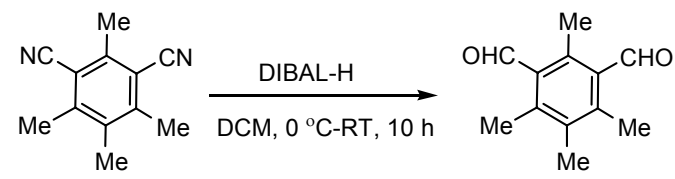

\section{Solution-state photolysis and photocyclization of ketones 1-6}

The photolysis of solutions of ketones 1-6 in anhyd benzene (3.0-4.0 $\left.\times 10^{-3} \mathrm{M}\right)$ contained in pyrex containers were purged with a $\mathrm{N}_{2}$ gas for ca. $20 \mathrm{~min}$ and subjected to photolysis in a Luzchem photoreactor ( $\lambda \approx 300$ and $350 \mathrm{~nm}$ for alkyl aryl and diaryl ketones, respectively). The typical duration of irradiation for aryl phenyl ketones and aryl benzyl ketones was $24 \mathrm{~h}$, while it was 60-72 $\mathrm{h}$ for alkyl aryl ketones. The progress of reaction in each case was monitored by TLC. The photolysates were subjected to silica-gel chromatography to isolate the photoproducts.

The results of photolysis for ketones 1 and $\mathbf{2}$ are shown in Scheme 2. As can be seen, the diaryl ketones 1a and 2a, and aryl alkyl ketones $\mathbf{1 b}, \mathbf{c}$ and $\mathbf{2 b , c}$ afford excellent yields (71-91\%) of bis-benzocyclobutenols (BCBs); the fact that the latter were indeed formed in a stepwise manner was established from ${ }^{1} \mathrm{H}$ NMR monitoring, from which, however, it was not possible to determine the relative ratios of mono- and diphotocyclization products with increasing duration of irradiation, see Supplementary Information. It should be noted that the diaryl ketones underwent reaction to completion within $24 \mathrm{~h}$, while the aryl alkyl ketones needed to be subjected to irradiation over an extended period of duration (ca. 60-72 h). Surprisingly, the aryl benzyl ketones $\mathbf{1 d}$ and $\mathbf{2 d}$ underwent reaction to completion within $24 \mathrm{~h}$ to afford a complex mixture of products. With a careful column chromatography, the corresponding BCBs were isolated in 50 and 40\% yields, respectively. The ketones 3, 4 and 6 yielded an intractable high polar material as monitored by TLC, and no characterizable product could be isolated from these cases. The behavior observed with ketone 5 was different in the sense that it yielded several products that could not be separated by column chromatography. 

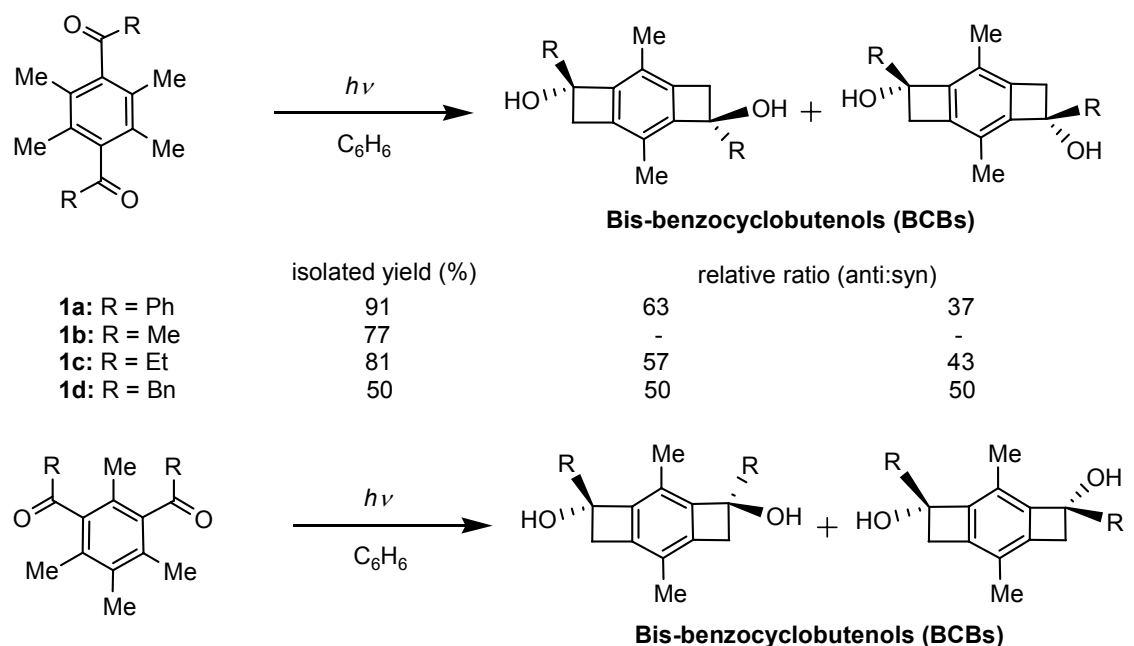

$$
\begin{aligned}
& \text { 2a: } R=P h \\
& \text { 2b: } R=M e \\
& \text { 2c: } R=E t \\
& \text { 2d: } R=B n
\end{aligned}
$$

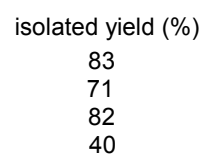

Bis-benzocyclobutenols (BCBs)

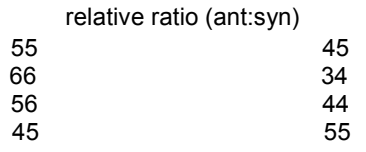

\section{Scheme 2}

The characterization of bis-benzocyclobutenols (BCBs) from ketones $\mathbf{1}$ and $\mathbf{2}$ was based on IR, ${ }^{1} \mathrm{H}$ and ${ }^{13} \mathrm{C}$ NMR analyses. In all cases, the photolyses led to a mixture of cis and trans bisbenzocyclobutenols, and these were subsequently separated by a careful silica-gel column chromatography; only in the case of diketone $\mathbf{1 b}$ that the diastereomeric cyclobutenols could not be separated. The stereochemistry of anti diols from 1a, 1c and 1d was established by X-ray crystallography. ${ }^{14}$ The second diastereomer was assigned 'syn' stereochemistry by default. A careful analysis of the ${ }^{1} \mathrm{H}$ NMR spectra for syn and anti diastereomers revealed a regular trend in the difference between the chemical shifts of the diastereotopic benzylic protons, i.e. $\Delta\left(\delta_{\mathrm{A}}-\delta_{\mathrm{B}}\right)$. The difference in the chemical shifts of the diastereotopic benzylic protons for the syn diastereomer was found to be consistently larger by $0.01-0.05 \mathrm{ppm}$ than that for the same protons in the anti diastereomer. This criterion was used to assign the stereochemistry for the benzocyclobutenols derived from ketones 2 . Indeed, this assignment was further corroborated by a very useful experimental finding that the more polar syn diols eluted invariably later than the anti diols in gravity silica-gel column chromatography. Thus, the relative ratios given in Scheme 2 are based upon isolated yields of the respective diastereomeric diols.

\section{Tandem photoenolization and Diels-Alder trapping of diketones with $\mathrm{N}$-phenylmaleimide}

The $\mathrm{N}_{2}$-purged solutions of diketones 1a, 2a, and 3-6 in benzene $\left(1.6 \times 10^{-2} \mathrm{M}\right)$ were subjected to preparative photolysis $(\lambda \simeq 350 \mathrm{~nm})$ in the presence of $N$-phenylmaleimide $\left(4.8 \times 10^{-2} \mathrm{M}\right)$. Photolysis in the case of 1a, 2a and 5 was continued for well over $24 \mathrm{~h}$. For these three ketones, no significant conversion to the products was observed. The ${ }^{1} \mathrm{H}$ NMR monitoring of the reaction of 1a, for example, revealed the formation of mono-trapped adduct and benzocyclobutenols in $<$ 
$10 \%$ yield. From a preparative photolysis of $1 \mathrm{a}$ in the presence of $\mathrm{N}$-phenylmaleimide for $30 \mathrm{~h}$, the monocycloaddition product was isolated in ca. $8 \%$ yield. (eq 3 ). In contrast, irradiation of ketones 3, 4, and $\mathbf{6}$ in the presence of

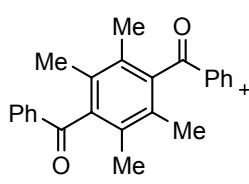<smiles>O=C1C=CC(=O)N1c1ccccc1</smiles>

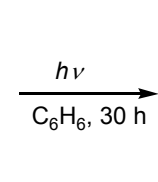

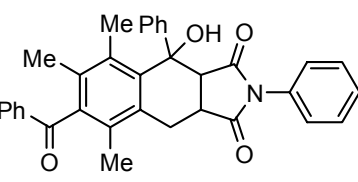

1a-DCA

$\mathrm{N}$-phenylmaleimide under similar conditions led to gradual disappearance of the diketones with concomitant formation of diastereomeric mixtures of diols. The photolysates were stripped off the solvent and subjected to dehydration in the presence of catalytic amount of PTS in toluene. After heating at reflux overnight, the reaction mixture was worked up to isolate the corresponding diastereomeric mixtures of trapped Diels-Alder cycloadducts (DCAs) in 87-90\% yields (Scheme 3). It is noteworthy that the formation of benzocyclobutenols was not observed at all under the experimental conditions of irradiation.

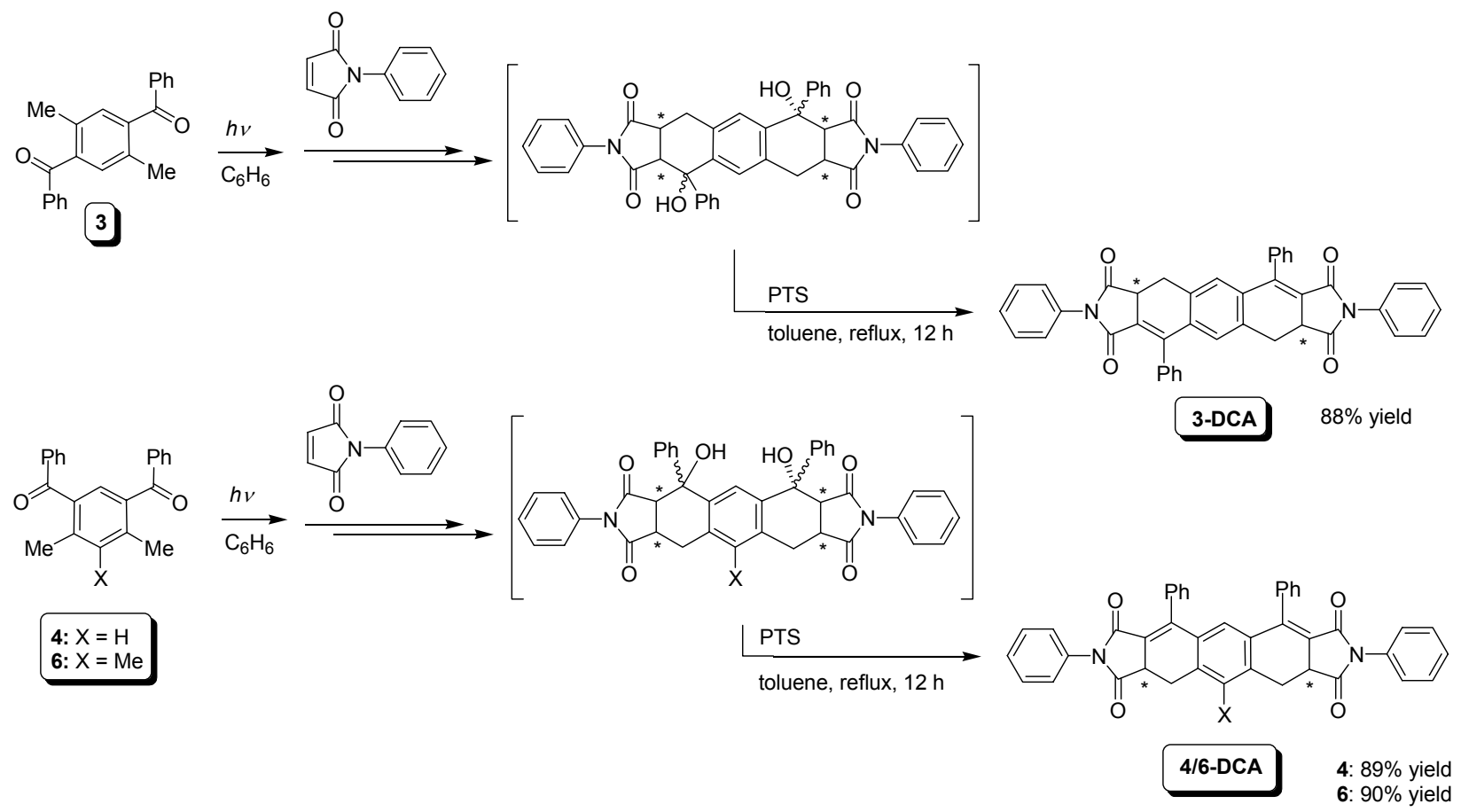

\section{Scheme 3}

Mechanistic rationalizations of i) the formation of bis-benzocyclobutenols and ii) 2-fold Diels-Alder trapping of bis-photoenols

As mentioned at the outset, there exists considerable controversy as to the mechanism of formation of benzocyclobutenols. From our solid-state studies, ${ }^{6 a}$ we have shown that $o$-alkyl 
aromatic aldehydes undergo cyclization in accordance with Wagner's mechanism. ${ }^{3}$ That is, the ground state $(E)$-enols precede the formation of benzocyclobutenols. Thus, the relative energy difference between $(E)$-photoenol and the corresponding benzocyclobutenol (see Scheme 1) may dictate the ease of unimolecular cyclization or bimolecular trapping of the dienol.

Each of the carbonyl groups in the methyl-substituted diketones 1-6 has accessible to it a $\gamma$ hydrogen for abstraction. Thus, initial photoexcitation must lead to mono-photoenolization in all of these ketones. There exists no evidence as yet for the reactions of $(Z)$-enols, which are believed to trace their path back rapidly to the precursor carbonyl compounds (Scheme 1) via a rapid thermal 1,5-sigmatropic shift. Thus, it is the $(E)$-enol intermediate that should be considered in rationalizing unimolecular cyclization and/or bimolecular Diels-Alder trapping with a dienophile, $N$-phenylmaleimide in the present study. We shall first consider the results of cyclization followed by discussion of why some photoenols are trapped by the dienophile, while some others are not.

The results in Scheme 2 show that photolysis of all ketones $\mathbf{1}$ and 2, with the exception of $\mathbf{1 d}$ and 2d, leads to excellent yields of bis-benzocyclobutenols (BCBs). The reason as to why the diketones 1d and 2d afford rather low yields of cyclobutenols should be reconciled from other competing processes such as Norrish Type I cleavage, which leads to a stable benzyl radical in these cases (eq 4). Although irradiation of diketone 5 appeared to yield products that are akin to benzocyclobutenols, a complex mixture of several products precluded isolation and

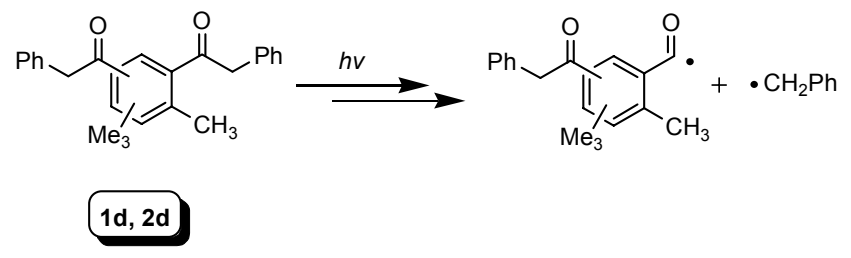

characterization; the ${ }^{1} \mathrm{H}$ NMR analysis of the photolyzed mixture revealed signals that are diagnostic of cyclobutenols. In principle, the diketone $\mathbf{5}$ may yield as many as four products and two diastereomers (eq 5). Presumably, a highly nonselective cyclization leads to a mixture of several products in this case. In contrast to the behavior of ketones $\mathbf{1 , 2}$ and $\mathbf{5}$, none of the ketones 3, 4 and $\mathbf{6}$ led to any isolable formation of mono- or bis-benzocyclobutenols. A feature

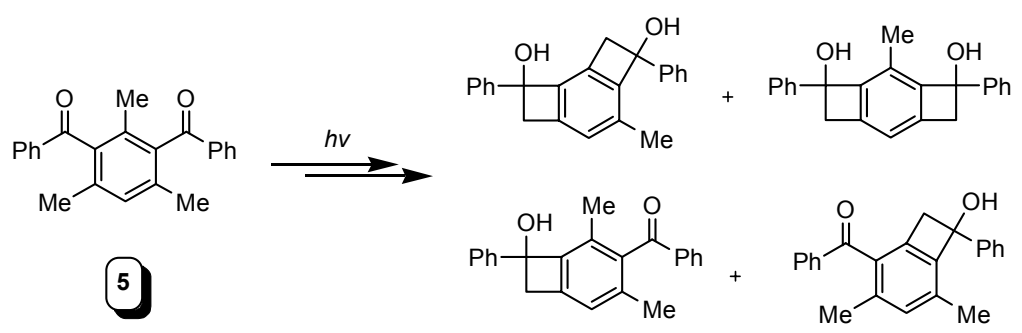

that distinguishes the former set with those of the latter is the difference in the steric crowding of their initially formed $(E)$-photodienols 7 and 8. Evidently, the steric congestion between Me and 


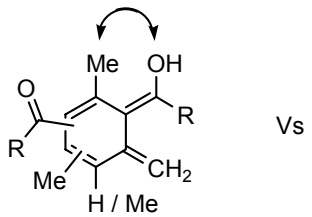

(7)

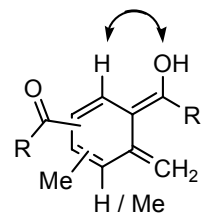

8

$\mathrm{OH}$ groups is significant to cause the photoenols derived from 1, 2 and 5 to become less stable relative to those derived from 3,4 and $\mathbf{6}$. Consequently, the thermal $4 \pi$-conrotatory closure is promoted in these cases to the corresponding relatively more stable benzocyclobutenols. Indeed, steric promotion of photocyclization of carbonyl compounds has been demonstrated long ago by Matsuura and coworkers. ${ }^{7}$ Be this as it may, it is intriguing that an intractable and highly polar material accumulates with increasing duration of irradiation of ketones $\mathbf{3}, \mathbf{4}$ and $\mathbf{6}$. We have shown recently that presence of an electron withdrawing group leads to stabilization of the dienols (electronic effect). ${ }^{6}$ Thus, in these cases, the initially formed photoenols $\mathbf{8}$, which are devoid of any steric congestion, are expected to be more stable to permit bimolecular thermal (hetero Diels-Alder cycloaddition with the carbonyl group of the precursor ketone) as well as other photochemical reactions (inherent to dienes) to occur efficiently to account for the observed intractable polymeric material; indeed, it should be noted that Meador and co-workers have utilized the photoenolization of diketone 3 in the synthesis of polymers. ${ }^{10 \mathrm{a}}$ The fact that a variety of monoketones undergo photocyclization to benzocyclobutenols, as shown by Wagner and coworkers, ${ }^{3 a}$ suggests that the location of a second electron withdrawing group as in ketones $\mathbf{3}$ and $\mathbf{4}$ modifies their reactivity.

For ketones 1 and $\mathbf{2}$ that undergo diphotocyclization readily, the formation of alternative bisbenzocyclobutenols 9 and 10 (Scheme 4), respectively, is not observed at all. This shows that the initially formed mono-benzocyclobutenol in these cases undergoes cyclization selectively to obviate the formation of angularly-fused dibenzocylobutenols $\mathbf{9}$ and $\mathbf{1 0}$ as shown in Scheme 4. Indeed, high isolated yields of bis-benzocyclobutenols from ketones $\mathbf{2}$ vindicates that the initial hydrogen abstraction leading to monocyclobutenol occurs highly regioselectively from the methyl that is para to the second carbonyl group.

Let us now consider the results of sequential 2-fold Diels-Alder trapping reaction of the dienols generated photochemically from ketones 1-6. In essence, all the ketones that exhibit efficient cyclization do not undergo trapping with $\mathrm{N}$-phenylmaleimide, an excellent dienophile. Irradiation of ketones $\mathbf{1 , 2}$ and $\mathbf{5}$ for $24 \mathrm{~h}$ in the presence of the dienophile led to no detectable bis-Diels-Alder trapping product. Intriguingly, the formation of bis-benzocyclobutenol (BCB) was found to be suppressed leading to recovery, predominantly, of the starting materials. On the other hand, those that yielded polymeric materials, i.e., 3, 4 and 6, upon photolyses underwent very efficient trapping in the presence of $N$-phenylmaleimide (Scheme 3). Clearly, the ketones in which the derived photoenols are devoid of steric influences undergo trapping. 


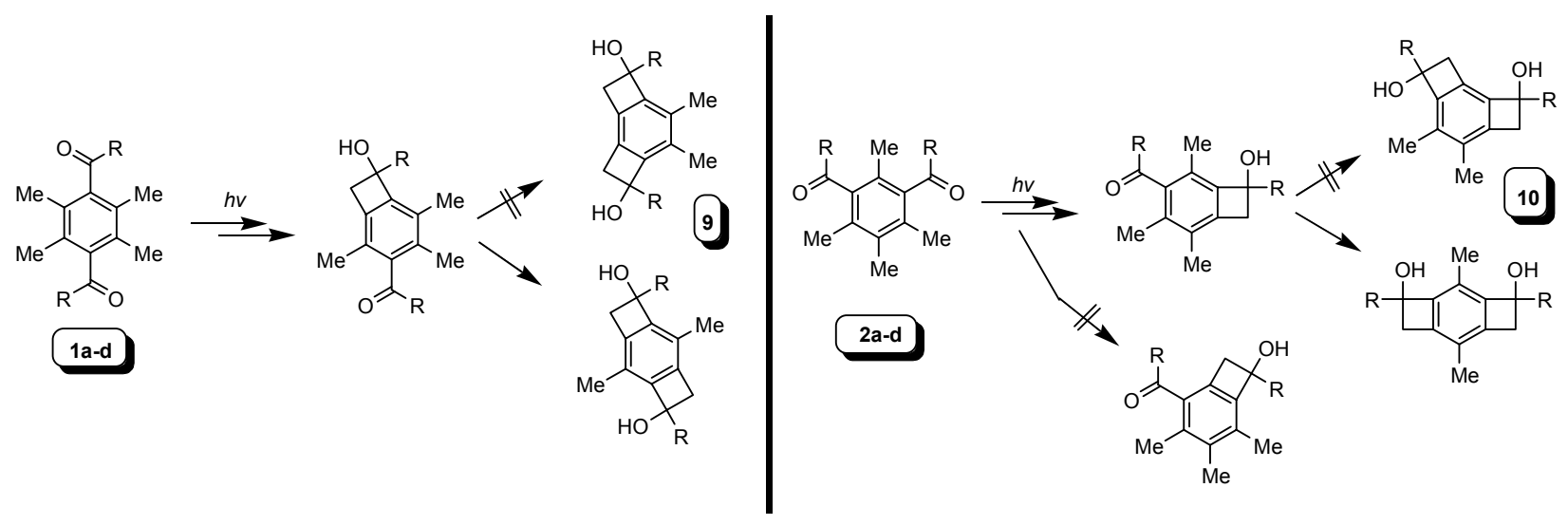

\section{Scheme 4}

To understand the behavior of ketones 1, 2 and $\mathbf{5}$ in the Diels-Alder trapping reaction, a careful ${ }^{1} \mathrm{H}$ NMR monitoring was carried out for the photolysis of $\mathbf{1 a}$ in the presence of $N$ phenylmaleimide. After extended irradiation in a Luzchem photoreactor ( $\lambda$ ca. $350 \mathrm{~nm}$ ) for 30-35 $\mathrm{h}$, the photolysate was directly analyzed by ${ }^{1} \mathrm{H}$ NMR spectroscopy, which revealed the formation of Diels-Alder cycloadduct and benzocyclobutenol in $<10 \%$ yield. The Diels-Alder product was isolated from a preparative photolysis and characterized to be a mono-trapping adduct (eq 3). Isolation of this product, albeit in low yields, is significant from two counts: first, it establishes the fact that the photoenols are indeed involved in the formation of benzocyclobutenols, which are exclusive products in the absence of a dienophile such as $N$-phenylmaleimide. In other words, the possibility of a different mechanistic pathway not involving the intermediacy of dienols en route to benzocyclobutenols, in the absence of a dienophile, in sterically-congested carbonyl compounds is ruled out. Second, this constitutes a first example, to the best of our knowledge, of trapping of a sterically-hindered photoenol. It is noteworthy that the trapping of the photoenol derived from 2,6-dimethylbenzophenone with dimethylacetylene dicarboxylate was reported long ago to be unsuccessful. ${ }^{\text {a }}$ The reason why 1a undergoes trapping should be traced to the presence of a benzoyl moiety, which may increase the lifetime of the enols to permit noticeable trapping. Otherwise, the inefficient formation of the mono-cycloaddition product and complete lack of formation of the bis-Diels-Adler cycloadduct suggest that the congested photoenols are too short lived to be trapped efficiently by a dienophile. But, the observation that the formation of bis-benzocyclobutenol is suppressed in the presence of the dienophile is quite intriguing. Presumably, the olefin quenches the triplet-excited biradical (= triplet-excited photoenol) to cause the photocyclization inefficient or the the photoenols revert rapidly to the precursor ketones; incidentally, the quantum yield for cyclization of sterically-congested analogous 2,4,6-trimethylbenzophenone is only $0.008 .^{7}$ 


\section{Conclusions}

We have examined the photoreactivity of dicarbonyl compounds containing $o$-methyl groups to understand the factors that favor i) diphotocyclization to synthetically useful bisbenzocyclobutenols and ii) 2-fold tandem photoenolization and Diels-Alder cycloaddition reactions. Based on the photochemical results of 1-6, we have uncovered a subtle role of steric and electronic factors on the cyclization as well as trapping reactions of the initially formed photoenols; while steric congestion of the photoenol promotes cyclization, ${ }^{18}$ electronic stabilization due to the presence of another electron-withdrawing carbonyl group causes bimolecular reactions to become competitive and suppress cyclization. Thus, 2-fold Diels-Alder trapping with an added dienophile, viz. $N$-phenylmaleimide, occurs efficiently when diketones that are devoid of steric congestion are subjected to photolysis. In view of the fact that hydroxyl groups can be reductively eliminated via catalytic hydrogenation, bis-benzocyclobutenols can be readily transformed into bis-benzocyclobutenes for which the scope in cross-polymerization reaction is abundant. Further, the knowledge of the steric and electronic factors in the trapping reactions of dicarbonyl compounds unraveled herein should have significant bearing on the exploitation of dicarbonyl compounds in the synthesis of highly fluorescent materials and polymers.

\section{Experimental Section}

General Procedures. Infrared spectra were run on Bruker Vector 22 FT-IR spectrophotometer and NMR spectra on JEOL $400 \mathrm{MHz}$ NMR spectrophotometer with deuterated solvents as internal standards. The melting points were determined with Perfit Melting Point Apparatus (Perfit India) and are uncorrected. THF and benzene were dried over sodium and benzophenone, DCM was distilled over $\mathrm{CaH}_{2}$. The commercial chemicals from Lancaster (UK), S.D.Fine Chemicals (India), DIBAL (ACROS ORGANICS) were used as purchased. Column chromatography was conducted on Silica gel (particle size: 60-120 $\mu$ ). Preparative photolyses were carried out in a Luzchem photoreactor.

Procedure for preparation of 2,4,5,6-tetramethylisophthalaldehyde and 4,5,6-trimethyl isophthalaldehyde by DIBAL-reduction of the precursor dicyanoderivatives

A $45.0 \mathrm{~mL}$ solution of 2,4,5,6-tetramethylisophthalonitrile $(8.2 \mathrm{mmol})$ in dichloromethane contained in a 2-necked round bottom flask was cooled to $0{ }^{\circ} \mathrm{C}$ in an ice bath under $\mathrm{N}_{2}$ atmosphere. To this solution was introduced slowly $17.5 \mathrm{~mL}$ (24.5 mmol) of DIBAL-H (1.4 M solution in toluene). The reaction mixture was gradually allowed to attain the room temperature. After stirring for $10 \mathrm{~h}$, it was quenched with dil $\mathrm{HCl}$ and heated at reflux for $30 \mathrm{~min}$. Subsequently, the reaction mixture was extracted with dichloromethane, dried over anhydrous $\mathrm{Na}_{2} \mathrm{SO}_{4}$, filtered and solvent was removed in vacuo. The residue was subjected to silica-gel 
column chromatography (EtOAc/pet. ether) to obtain the corresponding 2,4,5,6tetramethylisophthalaldehyde. A similar procedure was employed for the preparation of 4,5,6trimethylisolphthalaldehyde.

2,4,5,6-Tetramethylisophthalaldehyde. Yield $80 \%$, white crystalline solid; mp $174-175{ }^{\circ} \mathrm{C}$; IR (Neat) $1685 \mathrm{~cm}^{-1}$; NMR $\left(\mathrm{CDCl}_{3}, 400 \mathrm{MHz}\right) \delta 2.16(\mathrm{~s}, 3 \mathrm{H}), 2.37(\mathrm{~s}, 6 \mathrm{H}), 2.50(\mathrm{~s}, 3 \mathrm{H}), 10.52$ (s, $2 \mathrm{H}) ;{ }^{13} \mathrm{C} \mathrm{NMR}\left(\mathrm{CDCl}_{3}, 100 \mathrm{MHz}\right) \delta 15.3,16.7,133.7,135.5,136.8,141.3$, 195.4. Anal. Calc. for $\mathrm{C}_{12} \mathrm{H}_{14} \mathrm{O}_{2}$ (190) C, 75.76; H, 7.42. Found: C, 75.23; H, 7.03.

4,5,6-Trimethylisophthalaldehyde. Yield 75\%, white crystalline solid; mp 123-124 ${ }^{\circ} \mathrm{C}$; IR (Neat) $1672 \mathrm{~cm}^{-1} ;{ }^{1} \mathrm{H}$ NMR $\left(\mathrm{CDCl}_{3}, 400 \mathrm{MHz}\right) \delta 2.32(\mathrm{~s}, 3 \mathrm{H}), 2.69(\mathrm{~s}, 6 \mathrm{H}), 8.10(\mathrm{~s}, 1 \mathrm{H}), 10.30$ $(\mathrm{s}, 2 \mathrm{H}) ;{ }^{13} \mathrm{C} \mathrm{NMR}\left(\mathrm{CDCl}_{3}, 100 \mathrm{MHz}\right) \delta 15.3,15.7,132.4,134.3,139.1,144.5,192.2$. Anal. Calc. for $\mathrm{C}_{11} \mathrm{H}_{12} \mathrm{O}_{2}$ (176) C, 74.98; H, 6.86. Found: C, 74.56; H, 7.28.

\section{General procedure for the reaction of Grignard reagent with dialdehydes}

To a solution of phenylmagnesium bromide prepared from $\mathrm{Mg}$ turnings $(5.3 \mathrm{mmol})$ and bromobenzene $(4.8 \mathrm{mmol})$ in dry THF $(7 \mathrm{~mL})$ was added a solution of dialdehyde $(1.6 \mathrm{mmol})$ in $7 \mathrm{~mL}$ of anhyd THF drop wise at ca. $0{ }^{\circ} \mathrm{C}$ under $\mathrm{N}_{2}$ atmosphere. The reaction mixture was stirred at room temperature for $2 \mathrm{~h}$ and then quenched with saturated $\mathrm{NH}_{4} \mathrm{Cl}$. The solvent was removed in vacuo and the resulting reaction mixture was extracted with ethyl acetate. The organic layer was washed with brine solution, dried over anhyd $\mathrm{Na}_{2} \mathrm{SO}_{4}$, filtered and the solvent was removed in vacuo. The residue was subjected to a short pad silica-gel column chromatography (25\% EtOAc/pet. ether) to obtain the dialcohol (80-90\% yield), which was further subjected to PCC oxidation as described below to afford the diketone.

In order to synthesize the alkyl aryl ketones (1b-d, 2b-d), the alkylmagnesium halides (Me, Et, $\mathrm{Bn}$ ) in dry ether were treated with a solution of the corresponding precursor dialdehydes in THF by the procedure described above. The resulting dialcohols were subjected to PCC/Jones oxidation $^{11}$ to isolate ketones $\mathbf{1 b}-\mathbf{c}, \mathbf{2 b}-\mathbf{c}, \mathbf{1 d}$ and $\mathbf{2 d}$.

General procedure for PCC oxidation. To an ice-cold solution of dialcohol (1.2 mmol) in dry DCM (10mL) was added 3-Å molecular sieves followed by PCC (4.8 mmol). The reaction mixture was vigorously stirred at this temperature for $10 \mathrm{~min}$ and then stirred at room temperature for additional $2 \mathrm{~h}$. Subsequently, the reaction mixture was filtered over a short pad of silica-gel with $50 \%$ chloroform/pet. ether to obtain the diketone in $>90 \%$ yield.

1a. Colorless crystalline solid, mp $270-272{ }^{\circ} \mathrm{C}$; IR (KBr) $1664 \mathrm{~cm}^{-1} ;{ }^{1} \mathrm{H} \mathrm{NMR}\left(\mathrm{CDCl}_{3}, 400 \mathrm{MHz}\right)$ $\delta 2.02(\mathrm{~s}, 12 \mathrm{H}), 7.48(\mathrm{t}, J=7.6 \mathrm{~Hz}, 4 \mathrm{H}), 7.61(\mathrm{t}, J=7.3 \mathrm{~Hz}, 2 \mathrm{H}), 7.86(\mathrm{~d}, J=7.6 \mathrm{~Hz}, 4 \mathrm{H}) ;{ }^{13} \mathrm{C}$ $\mathrm{NMR}\left(\mathrm{CDCl}_{3}, 100 \mathrm{MHz}\right) \delta 16.5,128.9,129.6,130.5,133.9,136.9,140.5,201.4$. Anal. Calc. for $\mathrm{C}_{24} \mathrm{H}_{22} \mathrm{O}_{2}$ (342) C, 84.18; H, 6.48. Found: C, 84.40; H, 6.83.

2a. Colorless crystalline solid, mp $162-164{ }^{\circ} \mathrm{C}$; IR (Neat) $1669 \mathrm{~cm}^{-1} ;{ }^{1} \mathrm{H} \mathrm{NMR}\left(\mathrm{CDCl}_{3}, 400\right.$ $\mathrm{MHz}) \delta 1.83(\mathrm{~s}, 3 \mathrm{H}), 2.10(\mathrm{~s}, 6 \mathrm{H}), 2.22(\mathrm{~s}, 3 \mathrm{H}), 7.45(\mathrm{t}, J=7.7 \mathrm{~Hz}, 4 \mathrm{H}), 7.56-7.61$ (m, 2H), 7.84 $(\mathrm{d}, J=7.7 \mathrm{~Hz}, 4 \mathrm{H}) ;{ }^{13} \mathrm{C} \mathrm{NMR}\left(\mathrm{CDCl}_{3}, 100 \mathrm{MHz}\right) \delta 15.1,16.6,17.5,127.1,128.8,129.4,132.9$, 
133.7, 133.8, 137.0, 138.2, 200.7. Anal. Calc. for $\mathrm{C}_{24} \mathrm{H}_{22} \mathrm{O}_{2}$ (342) C, 84.18; H, 6.48. Found: C, 84.02; H, 6.99.

1b. Colorless crystalline solid, mp $181-182{ }^{\circ} \mathrm{C}\left(\operatorname{lit}^{15} 177-178{ }^{\circ} \mathrm{C}\right)$; IR (KBr) $1697 \mathrm{~cm}^{-1}$; ${ }^{1} \mathrm{H}$ NMR $\left(\mathrm{CDCl}_{3}, 400 \mathrm{MHz}\right) \delta 2.09(\mathrm{~s}, 12 \mathrm{H}), 2.44(\mathrm{~s}, 6 \mathrm{H}) ;{ }^{13} \mathrm{C} \mathrm{NMR}\left(\mathrm{CDCl}_{3}, 100 \mathrm{MHz}\right) \delta 16.1,32.7$, 128.5, 143.2, 209.1.

2b. Colorless crystalline solid, mp 122-124 ${ }^{\circ} \mathrm{C}\left(\operatorname{lit}^{16} 119-119.5{ }^{\circ} \mathrm{C}\right)$; IR (KBr) $1695 \mathrm{~cm}^{-1}$; ${ }^{1} \mathrm{H}$ $\mathrm{NMR}\left(\mathrm{CDCl}_{3}, 400 \mathrm{MHz}\right) \delta 2.06(\mathrm{~s}, 3 \mathrm{H}), 2.15(\mathrm{~s}, 9 \mathrm{H}), 2.44(\mathrm{~s}, 6 \mathrm{H}) ;{ }^{13} \mathrm{C} \mathrm{NMR}\left(\mathrm{CDCl}_{3}, 100 \mathrm{MHz}\right)$ $\delta 15.1,15.9,17.1,32.7,123.0,130.6,134.1,141.3,208.8$.

1c. Colorless crystalline solid, mp $179-180{ }^{\circ} \mathrm{C}\left(\right.$ lit $\left.^{15} 180-180.6{ }^{\circ} \mathrm{C}\right)$; IR (KBr) 1700, 2893, 2935 , $2975 \mathrm{~cm}^{-1} ;{ }^{1} \mathrm{H}$ NMR $\left(\mathrm{CDCl}_{3}, 400 \mathrm{MHz}\right) \delta 1.17(\mathrm{t}, J=7.3 \mathrm{~Hz}, 6 \mathrm{H}), 2.02(\mathrm{~s}, 12 \mathrm{H}), 2.65$ (q, $J=7.3$ $\mathrm{Hz}, 4 \mathrm{H}) ;{ }^{13} \mathrm{C} \mathrm{NMR}\left(\mathrm{CDCl}_{3}, 100 \mathrm{MHz}\right) \delta 7.4,16.2,38.4,128.7,143.1,211.9$.

2c. Colorless crystalline solid, mp 90-92 ${ }^{\circ} \mathrm{C}\left(\operatorname{lit}^{17} 99-100{ }^{\circ} \mathrm{C}\right)$; IR (KBr) 1699, 2893, 2935, 2977 $\mathrm{cm}^{-1}$; ${ }^{1} \mathrm{H} \mathrm{NMR}\left(\mathrm{CDCl}_{3}, 400 \mathrm{MHz}\right) \delta 1.18(\mathrm{t}, J=7.3 \mathrm{~Hz}, 6 \mathrm{H}), 1.98(\mathrm{~s}, 3 \mathrm{H}), 2.11(\mathrm{~s}, 6 \mathrm{H}), 2.15$ (s, $3 \mathrm{H}), 2.67$ (q, $J=7.3 \mathrm{~Hz}, 4 \mathrm{H}) ;{ }^{13} \mathrm{C} \mathrm{NMR}\left(\mathrm{CDCl}_{3}, 100 \mathrm{MHz}\right) \delta 7.5,15.1,16.0,17.2,38.4,123.5$, 130.9, 134.0, 141.3, 211.6 .

1d. Colorless crystalline solid, mp 202-203 ${ }^{\circ} \mathrm{C}$; IR (KBr) 1708, 2870, $3030 \mathrm{~cm}^{-1}$; ${ }^{1} \mathrm{H}$ NMR $\left(\mathrm{CDCl}_{3}, 400 \mathrm{MHz}\right) \delta 2.02(\mathrm{~s}, 12 \mathrm{H}), 3.99(\mathrm{~s}, 4 \mathrm{H}), 7.22-7.38(\mathrm{~m}, 10 \mathrm{H}) ;{ }^{13} \mathrm{C} \mathrm{NMR}\left(\mathrm{CDCl}_{3}, 100\right.$ $\mathrm{MHz}) \delta 16.3,52.2,127.2,128.6,129.1,129.9$, 132.8, 142.7, 207.9. Anal. Calc. for $\mathrm{C}_{26} \mathrm{H}_{26} \mathrm{O}_{2}$ (370) C, 84.29; H, 7.07. Found: C, 84.69; H, 6.69.

2d. Colorless crystalline solid, mp 130-131 ${ }^{\circ} \mathrm{C}$; IR (KBr) 1692, 2926, $3031 \mathrm{~cm}^{-1}$; ${ }^{1} \mathrm{H}$ NMR $\left(\mathrm{CDCl}_{3}, 400 \mathrm{MHz}\right) \delta 1.79(\mathrm{~s}, 3 \mathrm{H}), 2.02(\mathrm{~s}, 6 \mathrm{H}), 2.08(\mathrm{~s}, 3 \mathrm{H}), 3.87(\mathrm{~s}, 4 \mathrm{H}), 7.11-7.28(\mathrm{~m}, 10 \mathrm{H})$; ${ }^{13} \mathrm{C} \mathrm{NMR}\left(\mathrm{CDCl}_{3}, 100 \mathrm{MHz}\right) \delta 15.1,16.2,17.4,52.2,127.2,128.6,129.9,131.5,132.9,134.1$, 140.5, 207.5. Anal. Calc. for $\mathrm{C}_{26} \mathrm{H}_{26} \mathrm{O}_{2}(370) \mathrm{C}$, 84.29; H, 7.07. Found: C, 84.77; H, 7.39.

3. Colorless crystalline solid, mp $155-156{ }^{\circ} \mathrm{C}$; IR (Neat) $1665 \mathrm{~cm}^{-1} ;{ }^{1} \mathrm{H} \mathrm{NMR}\left(\mathrm{CDCl}_{3}, 400 \mathrm{MHz}\right)$ $\delta 2.27(\mathrm{~s}, 6 \mathrm{H}), 7.22(\mathrm{~s}, 2 \mathrm{H}), 7.49(\mathrm{t}, J=7.8 \mathrm{~Hz}, 4 \mathrm{H}), 7.60-7.64(\mathrm{~m}, 2 \mathrm{H}), 7.84(\mathrm{t}, J=7.8 \mathrm{~Hz}, 4 \mathrm{H})$; ${ }^{13} \mathrm{C} \mathrm{NMR}\left(\mathrm{CDCl}_{3}, 100 \mathrm{MHz}\right) \delta 19.3,128.6,130.1,130.4,133.4,133.5,137.1,140.4,198.2$. Anal. Calc. for $\mathrm{C}_{22} \mathrm{H}_{18} \mathrm{O}_{2}$ (314) C, 84.05; H, 5.77. Found: C, 83.88; H, 5.34.

4. Colorless crystalline solid, mp 107-108 ${ }^{\circ} \mathrm{C}$; IR (Neat) $1662 \mathrm{~cm}^{-1} ;{ }^{1} \mathrm{H} \mathrm{NMR}\left(\mathrm{CDCl}_{3}, 400 \mathrm{MHz}\right)$ $\delta 2.38(\mathrm{~s}, 6 \mathrm{H}), 7.24(\mathrm{~s}, 1 \mathrm{H}), 7.28(\mathrm{~s}, 1 \mathrm{H}), 7.41(\mathrm{t}, J=7.8 \mathrm{~Hz}, 4 \mathrm{H}), 7.54(\mathrm{t}, J=7.6 \mathrm{~Hz}, 2 \mathrm{H}), 7.76$ $(\mathrm{d}, J=7.8 \mathrm{~Hz}, 4 \mathrm{H}) ;{ }^{13} \mathrm{C} \mathrm{NMR}\left(\mathrm{CDCl}_{3}, 100 \mathrm{MHz}\right) \delta 20.0,128.5,129.3,130.1,133.3,134.0$, 135.3, 137.4, 139.7, 197.6. Anal. Calc. for $\mathrm{C}_{22} \mathrm{H}_{18} \mathrm{O}_{2}$ (314) C, 84.05; H, 5.77. Found: C, 84.56; H, 5.45 .

5. Colorless crystalline solid, mp $119-120{ }^{\circ} \mathrm{C}$; IR (Neat) $1668 \mathrm{~cm}^{-1} ;{ }^{1} \mathrm{H} \mathrm{NMR}\left(\mathrm{CDCl}_{3}, 400 \mathrm{MHz}\right)$ $\delta 1.88(\mathrm{~s}, 3 \mathrm{H}), 2.15(\mathrm{~s}, 6 \mathrm{H}), 7.01(\mathrm{~s}, 1 \mathrm{H}), 7.46(\mathrm{t}, J=7.8 \mathrm{~Hz}, 4 \mathrm{H}), 7.57-7.62(\mathrm{~m}, 2 \mathrm{H}), 7.83(\mathrm{t}, J=$ $7.8 \mathrm{~Hz}, 4 \mathrm{H}) ;{ }^{13} \mathrm{C} \mathrm{NMR}\left(\mathrm{CDCl}_{3}, 100 \mathrm{MHz}\right) \delta 16.9,19.4,128.9,129.5,129.6,130.6,133.9,135.0$, 136.8, 137.8, 200.1. Anal. Calc. for $\mathrm{C}_{23} \mathrm{H}_{20} \mathrm{O}_{2}$ (328) C, 84.12; H, 6.14. Found: C, 84.53; H, 6.43.

6. Colorless crystalline solid, mp 103-104 ${ }^{\circ} \mathrm{C}$; IR (Neat) $1663 \mathrm{~cm}^{-1} ;{ }^{1} \mathrm{H} \mathrm{NMR}\left(\mathrm{CDCl}_{3}, 400 \mathrm{MHz}\right)$ $\delta 2.28(\mathrm{~s}, 6 \mathrm{H}), 2.32(\mathrm{~s}, 3 \mathrm{H}), 7.06(\mathrm{~s}, 1 \mathrm{H}), 7.43(\mathrm{t}, J=7.8 \mathrm{~Hz}, 4 \mathrm{H}), 7.54-7.58(\mathrm{~m}, 2 \mathrm{H}), 7.81(\mathrm{~d}, J$ $=8.3 \mathrm{~Hz}, 4 \mathrm{H}) ;{ }^{13} \mathrm{C} \mathrm{NMR}\left(\mathrm{CDCl}_{3}, 100 \mathrm{MHz}\right) \delta 15.7,17.9,124.8,128.5,130.2,133.4,136.6(\times 2)$, 137.4, 137.9, 198.5. Anal. Calc. for $\mathrm{C}_{23} \mathrm{H}_{20} \mathrm{O}_{2}$ (328) C, 84.12; H, 6.14. Found: C, 83.73; H, 6.69. 


\section{General procedure for the photolysis of diketones}

A 3.0-4.0 mM solution of the diketone in dry denzene was taken in a pyrex tube, purged with $\mathrm{N}_{2}$ gas for $20 \mathrm{~min}$, and irradiated in a Luzchem photoreactor fitted with $\lambda \approx 350 \mathrm{~nm}$ lamps for aryl phenyl ketones and $\lambda \approx 300 \mathrm{~nm}$ for alkyl aryl ketones. The typical duration of irradiation for aryl phenyl ketones and aryl benzyl ketones was $24 \mathrm{~h}$, while it was 60-75 h for alkyl aryl ketones. The progress of the reaction in each case was monitored by TLC analysis. After photolysis, the solvent was removed in vacuo at room temperature $\left(25^{\circ} \mathrm{C}\right)$ and the residue was subjected to silica-gel chromatography (10\% ethyl acetate/pet. ether) to isolate dicyclobutenols and other photoproducts. Except in the case of diketone 1b, the diastereomeric bis-cyclobutenols from all other diketones were separated by a careful silica-gel column chromatography.

Anti 1a-BCB. Colorless solid; IR (KBr) $3339 \mathrm{~cm}^{-1}$; ${ }^{1} \mathrm{H}$ NMR $\left(\mathrm{CDCl}_{3}, 400 \mathrm{MHz}\right) \delta 1.45-1.75$ (br, $2 \mathrm{H}), 2.02(\mathrm{~s}, 6 \mathrm{H}), 3.39\left(\mathrm{AB}_{\mathrm{q}}, J_{\mathrm{AB}}=13.2 \mathrm{~Hz}, 2 \mathrm{H}\right), 3.45\left(\mathrm{AB}_{\mathrm{q}}, J_{\mathrm{AB}}=13.2 \mathrm{~Hz}, 2 \mathrm{H}\right), 7.28-7.30(\mathrm{~m}$, 2H), 7.33-7.37 (m, 4H) 7.44-7.47 (m, 4H); ${ }^{13} \mathrm{C} \mathrm{NMR}\left(\mathrm{CDCl}_{3}, 100 \mathrm{MHz}\right) \delta 12.7,49.2,80.6$, 125.4, 126.4, 127.5, 128.6, 140.4, 143.9, 148.0.

Syn 1a-BCB. Colorless solid; IR (KBr) $3280 \mathrm{~cm}^{-1}$; ${ }^{1} \mathrm{H}$ NMR $\left(\mathrm{CDCl}_{3}, 400 \mathrm{MHz}\right) \delta 1.45-1.80$ (br, $2 \mathrm{H}), 2.04(\mathrm{~s}, 6 \mathrm{H}), 3.38\left(\mathrm{AB}_{\mathrm{q}}, J_{\mathrm{AB}}=12.9 \mathrm{~Hz}, 2 \mathrm{H}\right), 3.46\left(\mathrm{AB}_{\mathrm{q}}, J_{\mathrm{AB}}=12.9 \mathrm{~Hz}, 2 \mathrm{H}\right), 7.27-7.30(\mathrm{~m}$, 2H), 7.33-7.38 (m, 4H), 7.45-7.48 (m, 4H); ${ }^{13} \mathrm{C} \mathrm{NMR}\left(\mathrm{CDCl}_{3}+\mathrm{DMSO}_{6}, 100 \mathrm{MHz}\right) \delta 12.1$, 48.2, 79.3, 125.0, 125.4, 126.4, 127.7, 139.5, 144.4, 147.7.

Anti 2a-BCB. Colorless solid; IR (KBr) $3457 \mathrm{~cm}^{-1}$; ${ }^{1} \mathrm{H}$ NMR $\left(\mathrm{CDCl}_{3}, 400 \mathrm{MHz}\right) \delta 1.33-1.70$ (br, $1 \mathrm{H}), 1.95(\mathrm{~s}, 3 \mathrm{H}), 2.09(\mathrm{~s}, 3 \mathrm{H}), 2.40-2.70(\mathrm{br}, 1 \mathrm{H}), 3.40\left(\mathrm{AB}_{\mathrm{q}}, J_{\mathrm{AB}}=13.9 \mathrm{~Hz}, 2 \mathrm{H}\right), 3.46\left(\mathrm{AB}_{\mathrm{q}}, J_{\mathrm{AB}}\right.$ $=13.9 \mathrm{~Hz}, 2 \mathrm{H}), 7.23-7.27(\mathrm{~m}, 2 \mathrm{H}), 7.30-7.34(\mathrm{~m}, 4 \mathrm{H}), 7.44-7.46(\mathrm{~m}, 4 \mathrm{H}) ;{ }^{13} \mathrm{C} \mathrm{NMR}\left(\mathrm{CDCl}_{3}, 100\right.$ $\mathrm{MHz}) \delta 12.4,48.9,80.2,124.8,125.1,127.2,127.4,128.3,141.7,143.6,146.3$.

Syn 2a-BCB. Colorless solid; IR (KBr) $3270 \mathrm{~cm}^{-1} ;{ }^{1} \mathrm{H} \mathrm{NMR}\left(\mathrm{CDCl}_{3}, 400 \mathrm{MHz}\right) \delta 1.33-1.70$ (br, $1 \mathrm{H}), 1.96(\mathrm{~s}, 3 \mathrm{H}), 2.09(\mathrm{~s}, 3 \mathrm{H}), 2.40-2.70(\mathrm{br}, 1 \mathrm{H}), 3.37\left(\mathrm{AB}_{\mathrm{q}}, J_{\mathrm{AB}}=13.9 \mathrm{~Hz}, 2 \mathrm{H}\right), 3.45\left(\mathrm{AB}_{\mathrm{q}}, J_{\mathrm{AB}}\right.$ $=13.9 \mathrm{~Hz}, 2 \mathrm{H}), 7.23-7.28(\mathrm{~m}, 2 \mathrm{H}), 7.31-7.35(\mathrm{~m}, 4 \mathrm{H}) 7.43-7.45(\mathrm{~m}, 4 \mathrm{H}) ;{ }^{13} \mathrm{C} \mathrm{NMR}\left(\mathrm{CDCl}_{3}, 100\right.$ $\mathrm{MHz}) \delta 12.4,49.0,80.3,124.9,125.1,127.2,127.7,128.3,141.9,143.6,146.4$.

Anti + Syn 1b-BCB. Colorless solid; IR (Neat) $3284 \mathrm{~cm}^{-1} ;{ }^{1} \mathrm{H}$ NMR $\left(\mathrm{CDCl}_{3}, 400 \mathrm{MHz}\right) \delta 1.67$ $(\mathrm{s}, 6 \mathrm{H}), 2.12(\mathrm{~s}, 6 \mathrm{H}), 2.98-3.19(\mathrm{~m}, 4 \mathrm{H}) ;{ }^{13} \mathrm{C} \mathrm{NMR}\left(\mathrm{CDCl}_{3}, 100 \mathrm{MHz}\right) \delta 12.1,24.8(\times 2), 46.4$, 46.5, 77.1, 125.6, 138.8, 148.7.

Anti 2b-BCB. Colorless solid; IR ( $\mathrm{KBr}) 3233 \mathrm{~cm}^{-1}$; ${ }^{1} \mathrm{H} \mathrm{NMR}\left(\mathrm{CDCl}_{3}, 400 \mathrm{MHz}\right) \delta 1.67(\mathrm{~s}, 6 \mathrm{H})$, $2.02(\mathrm{~s}, 3 \mathrm{H}), 2.23(\mathrm{~s}, 3 \mathrm{H}), 3.03\left(\mathrm{AB}_{\mathrm{q}}, J_{\mathrm{AB}}=13.9 \mathrm{~Hz}, 2 \mathrm{H}\right), 3.18\left(\mathrm{AB}_{\mathrm{q}}, J_{\mathrm{AB}}=13.9 \mathrm{~Hz}, 2 \mathrm{H}\right) ;{ }^{13} \mathrm{C}$ NMR $\left(\mathrm{CDCl}_{3}+\mathrm{DMSO}_{6}, 100 \mathrm{MHz}\right) \delta 11.8,12.1,25.6,45.8,75.7,123.1,126.2,139.3,147.9$.

Syn 2b-BCB. Colorless solid; IR (KBr) $3318 \mathrm{~cm}^{-1}$; ${ }^{1} \mathrm{H}$ NMR $\left(\mathrm{CDCl}_{3}, 400 \mathrm{MHz}\right) \delta 1.54-1.63$ (br, $1 \mathrm{H}), 1.69(\mathrm{~s}, 6 \mathrm{H}), 2.03(\mathrm{~s}, 3 \mathrm{H}), 2.10-2.21(\mathrm{br}, 1 \mathrm{H}), 2.23(\mathrm{~s}, 3 \mathrm{H}), 3.01\left(\mathrm{AB}_{\mathrm{q}}, J_{\mathrm{AB}}=13.9 \mathrm{~Hz}, 2 \mathrm{H}\right)$, $3.19\left(\mathrm{AB}_{\mathrm{q}}, J_{\mathrm{AB}}=13.9 \mathrm{~Hz}, 2 \mathrm{H}\right) ;{ }^{13} \mathrm{C} \mathrm{NMR}\left(\mathrm{CDCl}_{3}, 100 \mathrm{MHz}\right) \delta 11.9,12.3,24.9,46.5,77.0$, $123.9,127.3,140.3,147.5$.

Anti 1c-BCB. Colorless solid; IR (KBr) 2937, 2967, $3326 \mathrm{~cm}^{-1} ;{ }^{1} \mathrm{H} \mathrm{NMR}\left(\mathrm{CDCl}_{3}, 400 \mathrm{MHz}\right)$ $\delta 1.02(\mathrm{t}, J=7.6 \mathrm{~Hz}, 6 \mathrm{H}), 1.50-1.72(\mathrm{br}, 1 \mathrm{H}), 1.81-1.90(\mathrm{~m}, 2 \mathrm{H}), 1.98-2.07(\mathrm{~m}, 2 \mathrm{H}), 2.11(\mathrm{~s}, 6 \mathrm{H})$, $2.90\left(\mathrm{AB}_{\mathrm{q}}, J_{\mathrm{AB}}=13.0 \mathrm{~Hz}, 2 \mathrm{H}\right), 3.20\left(\mathrm{AB}_{\mathrm{q}}, J_{\mathrm{AB}}=13.0 \mathrm{~Hz}, 2 \mathrm{H}\right) ;{ }^{13} \mathrm{C} \mathrm{NMR}\left(\mathrm{CDCl}_{3}, 100 \mathrm{MHz}\right)$ $\delta 9.3,12.7,31.2,43.7,80.5,125.6,139.2,148.0$. 
Syn 1c-BCB. Colorless solid; IR (Neat) 2917, 2966, $3343 \mathrm{~cm}^{-1} 3285 ;{ }^{1} \mathrm{H} \mathrm{NMR}\left(\mathrm{CDCl}_{3}, 400\right.$ $\mathrm{MHz}) \delta 1.01(\mathrm{t}, J=7.6 \mathrm{~Hz}, 6 \mathrm{H}), 1.81-1.90(\mathrm{~m}, 2 \mathrm{H}), 1.94-2.05(\mathrm{~m}, 2 \mathrm{H}), 2.10(\mathrm{~s}, 6 \mathrm{H}), 2.84\left(\mathrm{AB}_{\mathrm{q}}\right.$, $\left.J_{\mathrm{AB}}=12.7 \mathrm{~Hz}, 2 \mathrm{H}\right), 3.19\left(\mathrm{AB}_{\mathrm{q}}, J_{\mathrm{AB}}=12.7 \mathrm{~Hz}, 2 \mathrm{H}\right) ;{ }^{13} \mathrm{C} \mathrm{NMR}\left(\mathrm{CDCl}_{3}, 100 \mathrm{MHz}\right) \delta 9.3,12.7$, 31.2, 43.7, 80.4, 125.6, 139.3, 148.2.

Anti 2c-BCB. Colorless solid; IR (KBr) 2914, 2973, $3331 \mathrm{~cm}^{-1} ;{ }^{1} \mathrm{H} \mathrm{NMR}\left(\mathrm{CDCl}_{3}, 400 \mathrm{MHz}\right)$ $\delta 1.02(\mathrm{t}, J=7.6 \mathrm{~Hz}, 6 \mathrm{H}), 1.52-1.67(\mathrm{br}, 1 \mathrm{H}), 1.81-1.90(\mathrm{~m}, 2 \mathrm{H}), 1.98-2.07(\mathrm{~m}, 2 \mathrm{H}), 2.02(\mathrm{~s}, 3 \mathrm{H})$, 2.12-1.22 (br, 1OH), $2.21(\mathrm{~s}, 3 \mathrm{H}), 2.90\left(\mathrm{AB}_{\mathrm{q}}, J_{\mathrm{AB}}=13.9 \mathrm{~Hz}, 2 \mathrm{H}\right), 3.19\left(\mathrm{AB}_{\mathrm{q}}, J_{\mathrm{AB}}=13.9 \mathrm{~Hz}, 2 \mathrm{H}\right)$; ${ }^{13} \mathrm{C} \mathrm{NMR}\left(\mathrm{CDCl}_{3}, 100 \mathrm{MHz}\right) \delta 9.3,12.3,13.1,31.3,43.7,80.4,124.2,127.0,140.7,146.9$.

Syn 2c-BCB. Colorless solid; IR (KBr) 2911, 2964, $3276 \mathrm{~cm}^{-1} ;{ }^{1} \mathrm{H}$ NMR $\left(\mathrm{CDCl}_{3}, 400 \mathrm{MHz}\right)$ $\delta 1.01(\mathrm{t}, J=7.6 \mathrm{~Hz}, 6 \mathrm{H}), 1.52-1.72(\mathrm{br}, 1 \mathrm{H}), 1.83-1.92(\mathrm{~m}, 2 \mathrm{H}), 1.97-2.06(\mathrm{~m}, 2 \mathrm{H}), 2.03(\mathrm{~s}, 3 \mathrm{H})$, $2.20(\mathrm{~s}, 3 \mathrm{H}), 2.87\left(\mathrm{AB}_{\mathrm{q}}, J_{\mathrm{AB}}=13.9 \mathrm{~Hz}, 2 \mathrm{H}\right), 3.20\left(\mathrm{AB}_{\mathrm{q}}, J_{\mathrm{AB}}=13.9 \mathrm{~Hz}, 2 \mathrm{H}\right) ;{ }^{13} \mathrm{C} \mathrm{NMR}\left(\mathrm{CDCl}_{3}\right.$, $100 \mathrm{MHz}) \delta 9.3,12.3,13.1,31.2,43.8,80.5,124.2,127.1,140.7,147.0$.

Anti 1d-BCB. Colorless solid; IR (Neat) 2918, $3411 \mathrm{~cm}^{-1} ;{ }^{1} \mathrm{H} \mathrm{NMR}\left(\mathrm{CDCl}_{3}, 400 \mathrm{MHz}\right) \delta 1.80$ $(\mathrm{s}, 6 \mathrm{H}), 2.83(\mathrm{~d}, J=12.9 \mathrm{~Hz}, 2 \mathrm{H}), 3.09\left(\mathrm{AB}_{\mathrm{q}}, J_{\mathrm{AB}}=13.7 \mathrm{~Hz}, 2 \mathrm{H}\right), 3.16\left(\mathrm{AB}_{\mathrm{q}}, J_{\mathrm{AB}}=13.7 \mathrm{~Hz}\right.$, $2 \mathrm{H}), 3.25(\mathrm{~d}, J=12.9 \mathrm{~Hz}, 2 \mathrm{H}), 7.20-7.27(\mathrm{~m}, 10 \mathrm{H}) ;{ }^{13} \mathrm{C} \mathrm{NMR}\left(\mathrm{CDCl}_{3}, 100 \mathrm{MHz}\right) \delta 12.4,44.5$, 44.9, 79.6, 126.0, 126.7, 128.4, 130.2, 137.9, 139.0, 147.7.

Syn 1d-BCB. Colorless solid; IR (Neat) 2961, $3404 \mathrm{~cm}^{-1} ;{ }^{1} \mathrm{H} \mathrm{NMR}\left(\mathrm{CDCl}_{3}, 400 \mathrm{MHz}\right) \delta 1.75$ (s, $6 \mathrm{H}), 1.85-2.23(\mathrm{br}, 2 \mathrm{H}), 2.79(\mathrm{~d}, J=13.2 \mathrm{~Hz}, 2 \mathrm{H}), 3.13\left(\mathrm{AB}_{\mathrm{q}}, J_{\mathrm{AB}}=13.4 \mathrm{~Hz}, 2 \mathrm{H}\right), 3.16\left(\mathrm{AB}_{\mathrm{q}}\right.$, $\left.J_{\mathrm{AB}}=13.4 \mathrm{~Hz}, 2 \mathrm{H}\right), 3.25(\mathrm{~d}, J=13.2 \mathrm{~Hz}, 2 \mathrm{H}), 7.24-7.26(\mathrm{~m}, 10 \mathrm{H}) ;{ }^{13} \mathrm{C} \mathrm{NMR}\left(\mathrm{CDCl}_{3}, 100 \mathrm{MHz}\right)$ $\delta 12.3,44.4,44.9,79.6,125.9,126.5,128.2,130.1,137.9,139.0,147.8$.

Anti 2d-BCB. Gummy liquid; IR (Neat) 2916, $3408 \mathrm{~cm}^{-1} ;{ }^{1} \mathrm{H} \mathrm{NMR}\left(\mathrm{CDCl}_{3}, 400 \mathrm{MHz}\right) \delta 1.81$ (s, $3 \mathrm{H}), 2.03(\mathrm{~s}, 3 \mathrm{H}), 2.91(\mathrm{~d}, J=13.9 \mathrm{~Hz}, 2 \mathrm{H}), 3.15\left(\mathrm{AB}_{\mathrm{q}} J_{\mathrm{AB}}=13.7 \mathrm{~Hz}, 2 \mathrm{H}\right), 3.24\left(\mathrm{AB}_{\mathrm{q}}, J_{\mathrm{AB}}=\right.$ $13.7 \mathrm{~Hz}, 2 \mathrm{H}), 3.35(\mathrm{~d}, J=13.9 \mathrm{~Hz}, 2 \mathrm{H}), 7.25-7.40(\mathrm{~m}, 10 \mathrm{H}) ;{ }^{13} \mathrm{C} \mathrm{NMR}\left(\mathrm{CDCl}_{3}, 100 \mathrm{MHz}\right) \delta$ 12.3, 12.7, 44.4, 44.9, 79.5, 124.8, 126.6, 127.0, 128.3, 130.1, 137.9, 140.5, 146.6.

Syn 2d-BCB. Gummy liquid; IR (Neat) 2916, $3404 \mathrm{~cm}^{-1} ;{ }^{1} \mathrm{H} \mathrm{NMR}\left(\mathrm{CDCl}_{3}, 400 \mathrm{MHz}\right) \delta 1.54$ (s, $3 \mathrm{H}), 1.85-2.20(\mathrm{br}, 2 \mathrm{H}), 1.91(\mathrm{~s}, 3 \mathrm{H}), 2.79(\mathrm{~d}, J=13.9 \mathrm{~Hz}, 2 \mathrm{H}), 3.09\left(\mathrm{AB}_{\mathrm{q}}, J_{\mathrm{AB}}=13.7 \mathrm{~Hz}, 2 \mathrm{H}\right)$, $3.15\left(\mathrm{AB}_{\mathrm{q}}, J_{\mathrm{AB}}=13.7 \mathrm{~Hz}, 2 \mathrm{H}\right), 3.24(\mathrm{~d}, J=13.9 \mathrm{~Hz}, 2 \mathrm{H}), 7.05-7.30(\mathrm{~m}, 10 \mathrm{H}) ;{ }^{13} \mathrm{C} \mathrm{NMR}\left(\mathrm{CDCl}_{3}\right.$, $100 \mathrm{MHz}) \delta 12.3,12.5,44.6,44.9,79.7,125.0,126.6,127.0,128.2,130.1,138.0,140.5,146.5$.

General procedure for trapping reaction of diketones $(3,4$ and 6) with $N$-phenylmaleimide followed by dehydration

A $20 \mathrm{ml}$ solution of the diketone $(0.32 \mathrm{mmol})$ and $\mathrm{N}$-phenylmaleimide $(0.96 \mathrm{mmol})$ in dry benzene was purged with $\mathrm{N}_{2}$ for 45 minutes and then subjected to photolysis with constant stirring under $\mathrm{N}_{2}$ atmosphere for $20 \mathrm{~h}$. After this period, the photolysate was stripped off the solvent under vacuum to afford an off-white mass, which was treated with toluene $(20 \mathrm{~mL})$ and catalytic amount of $p$-toluene sulphonic acid without further purification. The resulting suspension was refluxed overnight. The solvent was removed in vacuo and the residue obtained was dissolved in excess chloroform, washed with saturated $\mathrm{NaHCO}_{3}$ solution, brine solution, dried over anhydrous $\mathrm{Na}_{2} \mathrm{SO}_{4}$, filtered and the solvent removed in vacuo. The residue was subjected to a short pad silica-gel column chromatography (5-10\%EtOAc/chloroform) to afford 
the dehydrated Diels-Alder adduct (3-DCA/4-DCA/6-DCA) as an inseparable mixture of diastereomers. So, the characterization spectral data given below are for the mixtures.

The adduct 3-DCA was found to be highly insoluble. The purification of this product was carried out by suspending the solid material in a large excess of acetonitrile solvent and subjecting it to sonication for several hours.

In case of ketone 1a, the photolysate was stripped off the solvent under vacuum and the residue obtained was subjected to a silica-gel column chromatography (15\% EtOAc/pet. ether) to yield a colorless solid 1a-DCA.

1a-DCA. Yield 8\%, colorless solid, mp 192-194 ${ }^{\circ} \mathrm{C}$; IR (Neat) 1698, $3431 \mathrm{~cm}^{-1}$; ${ }^{1} \mathrm{H}$ NMR $\left(\mathrm{CDCl}_{3}, 400 \mathrm{MHz}\right) \delta 1.95(\mathrm{~s}, 3 \mathrm{H}), 2.00(\mathrm{~s}, 3 \mathrm{H}), 2.19-2.25(\mathrm{~m}, 1 \mathrm{H}), 2.47(\mathrm{~s}, 3 \mathrm{H}), 3.19-3.17(\mathrm{~m}$, $2 \mathrm{H}), 4.08(\mathrm{~d}, J=9.0 \mathrm{~Hz}, 1 \mathrm{H}), 5.77(\mathrm{~s}, 1 \mathrm{OH}), 6.92-6.95(\mathrm{~m}, 2 \mathrm{H}), 7.28-7.37(\mathrm{~m}, 9 \mathrm{H}), 7.43(\mathrm{t}, J=$ $7.5 \mathrm{~Hz}, 1 \mathrm{H}), 7.52(\mathrm{t}, J=7.3 \mathrm{~Hz}, 1 \mathrm{H}), 7.61(\mathrm{~d}, J=7.6 \mathrm{~Hz}, 2 \mathrm{H}) ;{ }^{13} \mathrm{C} \mathrm{NMR}\left(\mathrm{CDCl}_{3}, 100 \mathrm{MHz}\right) \delta$ $16.8,17.7,17.9,25.8,38.0,50.0,80.2,126.0,126.6,127.0,128.4,128.7,128.9,129.0,129.3$, 129.4, 129.8, 131.0, 133.2, 133.9, 135.7, 137.0, 140.06, 140.13, 140.3, 178.7, 180.3, 201.1.

3-DCA. Yield 88\%, off-white solid; IR (KBr) 1711, $1765 \mathrm{~cm}^{-1} ;{ }^{1} \mathrm{H}$ NMR (TFA + $\mathrm{CDCl}_{3}, 400$ $\mathrm{MHz}) \delta 3.13-3.21(\mathrm{~m}, 2 \mathrm{H}), 3.35-3.39(\mathrm{~m}, 2 \mathrm{H}), 4.12-4.16(\mathrm{~m}, 2 \mathrm{H}), 7.18-7.57(\mathrm{~m}, 22 \mathrm{H})$; ${ }^{13} \mathrm{C} \mathrm{NMR}$ $\left(\mathrm{CDCl}_{3}, 100 \mathrm{MHz}\right) \delta 29.0,41.3,121.8,127.5,129.0,130.3,130.8,130.9,134.0,136.3,136.4$, 138.2, 151.3, 169.8, 180.1.

4-DCA. Yield 89\%, colorless solid; IR (Neat) 1711, $1765 \mathrm{~cm}^{-1} ;{ }^{1} \mathrm{H} \mathrm{NMR}\left(\mathrm{CDCl}_{3}, 400 \mathrm{MHz}\right)$ 反 3.00-3.08 (m, 2H), 3.41-3.47 (m, 2H), 3.75-3.81 (m, 2H), $6.96(\mathrm{~s}, 1 \mathrm{H}), 7.15-7.42(\mathrm{~m}, 21 \mathrm{H}) ;{ }^{13} \mathrm{C}$ NMR $\left(\mathrm{CDCl}_{3}, 100 \mathrm{MHz}\right) \delta 29.0,29.7,40.0,40.2,121.3,121.6,126.4,126.5,127.5,127.6$, 128.4, 128.6, 128.7, 128.9, 129.1, 130.4, 131.1, 131.8, 133.4, 133.6, 134.9, 135.0, 138.1, 138.4, 146.0, 146.4, 165.7, 174.3, 174.4.

6-DCA. Yield 90\%, colorless solid; IR (Neat) 1709, $1763 \mathrm{~cm}^{-1} ;{ }^{1} \mathrm{H} \mathrm{NMR}\left(\mathrm{CDCl}_{3}, 400 \mathrm{MHz}\right)$ $\delta 1.48(\mathrm{~s}, 3 \mathrm{H}), 2.44-2.54(\mathrm{~m}, 2 \mathrm{H}), 2.75-2.84(\mathrm{~m}, 2 \mathrm{H}), 3.65-3.76(\mathrm{~m}, 2 \mathrm{H}), 6.47(\times 2), 7.08-7.38(\mathrm{~m}$, $20 \mathrm{H}) ;{ }^{13} \mathrm{C} \mathrm{NMR}\left(\mathrm{CDCl}_{3}, 100 \mathrm{MHz}\right) \delta 16.2(\times 2), 26.1(\times 2), 40.0,40.1,120.8,120.9,126.4,126.5$, $127.5,128.4,128.9,129.0(\times 2), 129.5(\times 2), 131.8(\times 2), 133.7,134.0,134.3(\times 2), 134.4,134.5$, $137.2,137.5,146.6,146.9,165.7,174.7,174.8$.

\section{Supplementary Information Available}

The NMR spectral scans for all the new compounds, thermally-labile benzocyclobutenols and Diels-Alder cycloadducts.

\section{Acknowledgements}

JNM is thankful to the department of science and technology (DST), India for generous financial support. SS is grateful to CSIR, India for a senior research fellowship. 


\section{References and Footnotes}

1. (a) Sammes, P. G. Tetrahedron 1976, 32, 405. (b) Segura, J. L.; Martin, N. Chem. Rev. 1999, 99, 3199. (c) Mehta, G.; Kotha, S. Tetrahedron 2001, 57, 625. (d) Kraus, G. A.; Zhao, G. J. Org. Chem. 1996, 61, 2770. (e) Arnold, B. J.; Sammes, P. G.; Wallace, T. W. J. Chem. Soc., Perkin Trans. I 1974, 409. (f) Arnold, B. J.; Sammes, P. G.; Wallace, T. W. J. Chem. Soc., Perkin Trans. I 1974, 415. (g) Charlton, J. L.; Koh, K. Synlett 1990, 333. (h) Charlton, J. L.; Plourde, G. L.; Koh, K.; Secco, A. S. Can. J. Chem. 1990, 68, 2022. (i) Zhang, X.; Foote, C. S. J. Org. Chem. 1994, 59, 5235.

2. (a) Fitzgerald, J. J.; Michael, F. E.; Olofson, R. A. Tetrahedron Lett. 1994, 35, 9191. (b) Fitzgerald, J. J.; Pagano, A. R.; Sakoda, V. M.; Olofson, R. A. J. Org. Chem. 1994, 59, 4117. (c) Fitzgerald, J. J.; Drysdale, N. E.; Olofson, R. A. J. Org. Chem. 1992, 57, 7122. (d) Dougeherty, C. M.; Olofson, R. A. J. Am. Chem. Soc. 1973, 95, 581.

3. (a) Wagner, P. J.; Subrahmanyam, D.; Park, B. S. J. Am. Chem. Soc. 1991, 113, 709. (b) Wagner, P. J.; Sobczak, M.; Park, B. S. J. Am. Chem. Soc. 1998, 120, 2488. (c) Sobczak, M.; Wagner, P. J. Tetrahedron Lett. 1998, 39, 2523.

4. Scaiano, J. C.; Wintgens, V.; Netto-Ferreira, J. C. Tetrahedron Lett. 1992, 33, 5905.

5. (a) Yang, N. C.; Rivas, C. J. Am. Chem. Soc. 1961, 83, 2213. (b) Heindel, N. D.; Sarver, E. W. Tetrahedron Lett. 1968, 9, 3579. (c) Quinkert, G.; Stark, H. Angew. Chem., Int. Ed. Engl. 1983, 22, 637. (e) Nicolaou, K. C.; Snyder, S. A.; Motagnon, T.; Vassilikogiannakis, G. Angew. Chem., Int. Ed. 2002, 41, 1668.

6. (a) Moorthy, J. N.; Mal, P.; Natarajan, R.; Venugopalan, P. J. Org. Chem. 2001, 66, 7013. (b) Mal, P.; Lourderaj, U.; Parveen.; Venugopalan, P.; Moorthy, J. N.; Sathyamurthy, N. J. Org. Chem. 2003, 68, 3446.

7. (a) Matsuura, T.; Kitaura, Y. Tetrahedron Lett. 1967, 8, 3309. (b) Matsuura, T.; Kitaura, Y. Tetrahedron 1969, 25, 4487. (c) Kitaura, Y.; Matsuura, T. Tetrahedron 1971, 27, 1597.

8. (a) Tietze, L. F. Chem. Rev. 1996, 96, 115. (b) Winkler, J. D. Chem. Rev. 1996, 96, 167.

9. (a) Moorthy, J. N.; Mal, P.; Singhal, N.; Venkatakrishnan, P.; Malik, R.; Venugopalan, P. $J$. Org. Chem. 2004, 69, 8459. (b) Koner, A. L.; Singhal, N.; Nau, W, M.; Moorthy, J. N. J. Org. Chem. 2005, 70, 7439.

10. (a) Meador, M. A. B.; Meador M. A.; Williams, L. L.; Scheiman, D. A. Macromolecules 1996, 29, 8983. (b) Meador, M. A. Spectrum 2003, 16, 22. (c) Ilhan, F.; Tyson, D. S.;

Stasko, D. J.; Kirschbaum, K.; Meador, M. A. J. Am. Chem. Soc. 2006, 128, 702. (d) Ilhan, F.; Tyson, D. S.; Meador, M. A. Org. Lett. 2006, 8, 577.

11. Harding, K. E.; May, L. M.; Dick, K. F. J. Org. Chem. 1975, 40, 1664.

12. Yakubov, A. P.; Tsyganov, D. V.; Belenkii, L. I.; Krayushkin, M. M. Tetrahedron 1993, 49, 3397.

13. Binger, F. M.; Ugelow, I. J. Am. Chem. Soc. 1953, 75, 2623.

14. The X-ray crystal structure details of the dis-benzocyclobutenols will be published separately elsewhere. 
15. Pinkus, A. G. Organic Preparation and Procedures International 1978, 10, 255.

16. Andreou, A. D.; Bulbulian, R. V.; Gore, P. H. Tetrahedron 1980, 36, 2101.

17. Suzuki, H.; Aomori, Y.; Mishina, T.; Hanafusa, T. Bull. Chem. Soc. Japan 1978, 51, 3393.

18. The methyl substituents in the ring are known to produce only a small inductive effect on hydrogen atom abstraction by $n, \pi^{*}$ ketone triplets, see: Wagner, P. J.; Truman, R. J. Scaiano, J. C. J. Am. Chem. Soc. 1985, 107, 7093. 